\title{
ERYTHROPOIETIN RESTORES MOTOR FUNCTIONS THROUGH ANGIOGENESIS IN THE THALAMUS AREA OF ISCHEMIC STROKE IN RATS
}

\author{
Rifda Naufa Lina, Mahardian Rahmadi, Junaidi Khotib \\ Department of Clinical Pharmacy, Faculty of Pharmacy, Universitas Airlangga, Surabaya, Indonesia
}

\section{ABSTRACT}

\begin{abstract}
The present study aimed to determine the potency of erythropoietin as angiogenesis inducer in ischemic stroke rats model. Animal model was treated by right unilateral common carotid artery occlusion (rUCCAO) for 90 minutes. The stroke model produced decreased motor function. Eight to 12 week-old Wistar rats were used. rHuEPO was administered for 7 days, starting at 24 hours after stroke induction. Motor functions were measured before and 1, 3 and 7 days after rUCCAO. Whereas, histological damage and VEGF expression were evaluated at day 14. The results showed that rHuEPO significantly increased motor function on day 7 , reduced the number of damaged body cell and increased VEGF expression in the thalamus area on day 14 . As a conclusion, rHuEPO may restore the motoric function and prevent brain neuronal death by inducing angiogenesis through the increase in the expression of VEGF in rUCCAO-induced ischemic stroke model.
\end{abstract}

Keywords: rHuEPO; ischemic stroke; motor function; angiogenesis; VEGF

\section{ABSTRAK}

Penelitian ini bertujuan untuk mengetahui potensi eritropoeitin sebagai inducer angiogenesis pada stroke iskemik dengan model hewan tikus. Model hewan dilakukan dengan right unilateral commond carotid artery occlusion (rUCCAO) selama 90 menit. Keberhasilan model stroke ini dilihat dengan menurunnya fungsi motorik. Penelitian ini menggunakan tikus wistar usia 8-12 minggu. rHuEPO diberikan selama 7 hari dimulai 24 jam setelah induksi stroke. Fungsi motorik diukur sebelum melakukan induksi rUCCAO dan setelah rUCCAO pada hari ke-1, 3 dan 7, histologi dan ekspresi VEGF diuji pada hari ke-14 di area talamus. Sebagai simpulan, rHuEPO mungkin memperbaiki fungsi motorik dan mencegah kematian neuron otak dengan menginduksi angiogenesis melalui peningkatan ekspresi VEGF pada induksi stroke iskemik dengan model rUCCAO.

Kata kunci: rHuEPO; stroke iskemik; fungsi motorik; angiogenesis; VEGF

Correspondence: Junaidi Khotib, Department of Clinical Pharmacy, Faculty of Pharmacy, Campus B Universitas Airlangga. Jl. Dharmawangsa Dalam, Surabaya 60286, East Java, Indonesia. Phone: +62-315033710. Fax: +62315020514. E-mail: junaidi-k@ff.unair.ac.id

pISSN:2355-8393 • eISSN: 2599-056x • doi: http://dx.doi.org/10.20473/fmi.v54i3.10011

- Fol Med Indones. 2018;54:189-19 • Received 27 Oct 2017 • Accepted 26 Apr 2018

- Open access under CC-BY-NC-SA license • Available at https://e-journal.unair.ac.id/FMI/

\section{INTRODUCTION}

Stroke is one of common causes of disability and death (Park et al 2014). Ischemic stroke is caused by focal occlusion of cerebral blood vessels, leading to the decrease in oxygen and nutrition supply to the brain and causing neuronal death in certain brain area (Park et al 2014, Hacke et al 2003). Occlusion can be thrombus, embolus, or thromboembolic which can cause hypoxia to anoxia at one of the branching of blood vessels in the brain (Bruno et al 2000). Approximately 30.7 million people in the world suffer from stroke every year. Around 800,000 primary or recurrent strokes happen each year in the U.S., with the most common are primary strokes. Approximately $87 \%$ are ischemic infarctions, $10 \%$ are primary hemorrhages, and $3 \%$ are subarachnoid hemorrhage (Ovbiagele \& Huynh 2011).

In ischemic stroke, reduced blood flow to the brain causes hypoxemia of the brain region causing infarct core and penumbra that ends with cell death (Gonzalez et al 2011). Ischemic penumbra was defined as underperfused brain tissue at level within the thresholds of functional impairment and morphological integrity. The penumbra area has the capacity to recover if perfusion is restored. The core is generally defined as that part of the ischemic region that is irreversibly injured (Gonzalez et al 2011). It can be induced by microglia activation and release several cytokines such as IL-1 and TNF- $\alpha$ that is a member of the cell death receptor (Jin et al 2010, Deb 
et al 2009, Pun et al 2009, Vikman et al 2007). Thus, the study suggested ischemic stroke therapy targeted to the ischemic penumbra.

Hypoxia induces cells to respond through multiple gene products, such as EPO and VEGF, that will improve oxygen delivery to the tissues. The induction of EPO and EPOR by hypoxia suggests that EPO administration has a therapeutic potential role for tissue damage from ischemia or hypoxia in the central nervous system (Ribatti et al 2003). A critical molecular pathway induced by hypoxia/ischemia is the activation of hypoxiainducible factor 1, a transcriptional activator of genes encoding VEGF and other important mediators of angiogenesis. Hif $1 \alpha$ is the central transcriptional factor for the regulation of oxygen-associated genes in response to hypoxia (Gandin et al 2016). In the key restorative mechanisms in response to stroke, there is increasing evidences that angiogenesis, through new blood vessel formation, results in improved collateral circulation and may impact the long-term recovery of the patients (Gandin et al 2016).

Recombinant EPO may also provide neuroprotection via its interaction with other growth factors, such as vascular endothelial growth factor (VEGF) and insulin growth factor (IGF-1). EPO has robust angiogenic effects and works synergistically with VEGF. Increased angiogenesis during recovery from a stroke injury might improve oxygen transport to healing brain areas (Hoke 2006). EPO/EPOR mRNA and protein were detected in several regions of the murine and primate brain, including cortex, hippocampus, amygdala, cerebellum, hypothalamus, and caudate nucleus. Recent findings show that astrocytes are the main source of EPO in the brain. Moreover, it has been shown in in vitro and in vivo studies that neurons express EPO. Similarly, EPO receptor (EPOR) is expressed on neurons and astrocytes. EPO promotes cell survival through inhibiting apoptosis. In erythroid cells, after EPO binds to its EPOR, Janus tyrosine kinase 2 (JAK2) is phosphorylated and activated. This leads to engaging secondary signaling molecules, such as signal transducer and activator of transcription 5 (STAT5), followed by the activation of Ras mitogen activated protein kinase (MAPK), ERK-1/-2, and PI3K/Akt. Moreover, EPO induced the upregulation of the anti-apoptotic protein BCL-XL (Rabie \& Marti 2008). PI3K/Akt and ERK1/2 signaling pathways mediate VEGF secretion by the interaction of exogenous EPO with EPOR in neural progenitor cells. Furthermore, VEGF secreted by neural progenitor cells along with VEGFR2 in cerebral endothelial cells promotes angiogenesis (Wang et al 2008). EPO increases VEGF that mediates rHuEPO-induced angiogenesis (Wang et al 2004).
Since EPO may induce angiogenesis, it is possible that the motoric defect after ischemic stroke-induced transient right unilateral common carotid artery is ameliorated by EPO treatment. We hypothesized that EPO induces angiogenesis to improve the collateral circulation, leading to the sufficient supply to penumbra area and, finally, inhibit neuronal death in the brain after stroke.

\section{MATERIALS AND METHODS}

The materials used in the experiment were $\mathrm{rHu}$ Erythropoietin alfa (PT Daewoong Infion), normal saline, distilled water, buffered-formalin $10 \%$, hematoxylin-eosin (Sigma Aldrich), xylazine, midazolam, and VEGF antibody (Thermofisher).

\section{Animals}

Male 8-12 week-old rats (Rattus norvegicus), weighing 140-240 g were used. The rats were acclimated for 1-2 weeks in a group of 3 individuals per polypropylene cage. All animals were housed on a $12 \mathrm{~h}$ light/dark cycle at a temperature of $22-24^{\circ} \mathrm{C}$ and humidity of $40-$ $50 \%$. They were fed on commercial pellets (pellets 594, Indonesia) and tap water ad libitum. The number of animals used was 30. Animal care and experimentation were conducted in animal laboratory of Universitas Airlangga, Surabaya, Indonesia.

\section{Animal study design}

To examine whether treatment with EPO promote functional recovery, as inducer angiogenesis, rHUEPO (epoetin a, 3,000 IU/ $0.3 \mathrm{ml}$; PT. Daewoong Infion, Pasuruan, Indonesia) was intravenously administered in a dose of 1,000 IU (n=6); 5,000 IU $(n=6)$, and 10,000 IU (n=6), daily for 7 days starting at 24 hours after rUCCAO. Doses of rHuEPO were selected based on previous studies (Wang et al 2004). Ischemic rats $(n=6)$ treated with the same volume were used as a control group. All rats were euthanized 14 days after stroke. Three rats in each group were used to examine the effect of rHuEPO on brain levels of VEGF and large of infarct area.

\section{Induction of ischemia}

Transient right unilateral common carotid artery occlusion (rUCCAO) is the method for inducing stroke. Rats were anaesthetized with combination of ketamin (80 $\mathrm{mg}$ ) and Xylazine $(10 \mathrm{mg})$ intramuscularly. After the animals were deeply anaesthetized, they were kept in supine position under an operating lamp. A midline neck incision was done between manubrium and the 
jaw. The underlying muscle fascia and submandibular glands were bluntly dissected to expose the right common carotid artery (rCCA). The isolated rCCA was temporarily clamed with bulldog clam for 90 minutes. After 90 minutes the bulldog clam was opened. The midline neck incision was sewed using surgical suture. To relieve pain and discomfort in the postoperative period, topical Lidocaine gel was applied on the wound and the animal received $0.5 \mathrm{ml}$ saline intraperitoneally as volume replenishment after the surgery.

\section{Behavioral tests}

Forelimb Use Asymmetry Test

Behavioral test was performed before rUCCAO induction and on days 1, 3, and 7 after rUCCAO. Forelimb use during exploratory activity was analyzed by videotaping the rats in a transparent cylinder $(20$ in $\mathrm{cm}$ diameter and $30 \mathrm{~cm}$ in height) for 3 to 10 minutes, depending on the degree of activity during the trial. A mirror was placed to the side of the cylinder at an angle to enable the recording of forelimb movements even when the animal was turned away from the camera. Scoring was done by an experimenter blinded to the condition of the animal using a video recorder with slow motion and clear stop frame capabilities. The behavior was scored according to the following criteria: (1) independent use of the left or right forelimb for contacting the wall during a full rear to initiate a weightshifting movement or to regain center of gravity while moving laterally in a vertical posture and (2) simultaneous use of both the left and right forelimbs for contacting the cylinder wall during a full rear and for alternating lateral stepping movements along the wall.

Behavior was quantified by determining the occasions when the unimpaired (ipsilateral) forelimb was used as a percentage of total number of limb use observations on the wall (I); the occasions when the impaired forelimb (contralateral to the blood injection site) was used as a percentage of total number of limb use observations on the wall $(\mathrm{C})$; and the occasions when both forelimbs were used simultaneously (or nearly simultaneously during lateral side-stepping movements) as a percentage of total number of limb use observations on the wall (B). A single overall limb use asymmetry score was calculated as follows: Limb Use Asymmetry Score = $[\mathrm{I} /(\mathrm{I}+\mathrm{C}+\mathrm{B})]-[\mathrm{C} /(\mathrm{I}+\mathrm{C}+\mathrm{B})]$ (Hua et al 2002).

\section{Histological examination}

Three animals in each group were perfusion-fixed in 14 days after transient rUCCAO and sham- operation, and post-fixed with $10 \%$ paraformaldehyde in PBS (pH 7.4). Paraffin-embedded brains were sectioned at $10 \mu \mathrm{m}$.
Hematoxylin and eosin (HE) staining was performed to identify morphologically normal and ischemic neurons as usual.

\section{Immunohistochemistry}

Three animals in each group were used exclusively for this study. Immunohistochemical analysis using VEGF polyclonal antibody (PA1-21796; Thermo Fisher Scientific, USA; diluted 1:50) as primer antibody was used for the assessment of neuronal injury. All these procedures were carried out in the Faculty of Veterinary Medicine, Universitas Airlangga, Surabaya.

\section{Statistical analysis}

Statistical analysis was performed using Graph-Pad Prism software version 6.0. Behavioral data were analyzed using Two-way analysis of variance (ANOVA) followed by Bonferroni post-hoc test. Infarction size data were compared among treatment groups. For immunohistochemistry, data were analyzed using One-way ANOVA. Data were presented as means \pm SEM. A value of $\mathrm{p}<0.05$ was considered significant.

\section{RESULTS}

\section{Behavioral assessment}

The behaviors of the rats with transient rUCCAO surgery were examined before rUCCAO induction and on days 1, 3, and 7 after rUCCAO. In forelimb use asymmetry test (FUAT), the percentage of rat limb exploration in cylindrical tube showed a significant increase on the 7 th day ( $p<0.05$, Fig. 1$)$.

\section{Histological assessment}

In this study, the histologic appearance of brain tissue showed the number of normal and damaged body cells of the neurons in the thalamus area. Stroke group experienced the highest number of cell damage compared to other groups. The group with rHuEPO therapy and the group with rHuEPO $10000 \mathrm{IU}$ experienced the least amount of damage (Fig. 2).

\section{Immunohistochemistry assessment}

In this study, the immunohistochemistry appearance of brain tissue shows the VEGF expression in the thalamus area (Figs. 3 and 4).

\section{DISCUSSION}

Our data indicated that treatment with rHuEPO 24 hours after stroke for 7 days significantly improved motor function and reduced the number of damaged body cell 
and induced angiogenesis via regulation of VEGF in ischemic stroke. Treatment with rHuEPO for 7 days significantly improved motor function.

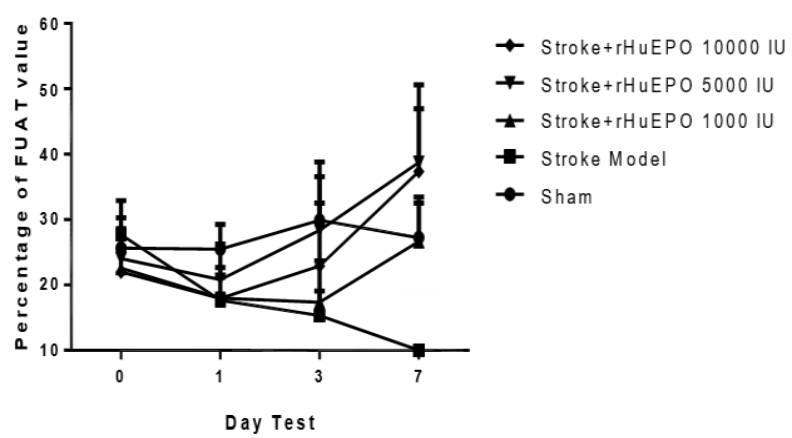

Fig. 1 Effect of rHuEPO on the motor function of rats represented by the percentage of FUAT value. Measurements were performed on the sham group, stroke model, and stroke model with rHuEPO doses of 1000 IU, 5000 IU and 10,000 IU from day 0 to day 7 . Significant differences were seen on day 7 in sham group vs stroke model $(\mathrm{p}=0.0139)$, stroke model vs rHuEPO of $1.000 \mathrm{IU}(\mathrm{p}=0.0121)$, stroke model vs rHuEPO of $5.000 \mathrm{IU}(\mathrm{p}=0.0005)$ and stroke model vs. rHuEPO of $10.000 \mathrm{IU}(\mathrm{p}=0.0121) . * \mathrm{p}<0.05$ vs stroke model.
Thalamus is known to regulate the process of motion. The ventrolateral, ventroanterior and ventrointermedial parts of thalamus are responsible in coordination and initiation of movement. EPO treatment provides neuroprotection when initiated soon after injury, with beneficial effects largely attributed to decrease in neuronal apoptosis (Siren et al 2001). Hypoxia induces cells to respond through multiple gene products, such as EPO and VEGF, that will improve oxygen delivery to the tissues. The induction of EPO and EPOR by hypoxia suggests that EPO administration has a therapeutic potential role for tissue damage from ischemia or hypoxia in the central nervous system (Ribatti et al 2003). EPO has been shown to improve sensorimotor and cognitive deficits in rats after both CCI and cryogenic lesion injuries (Hellewell et al 2013), so it reduces cell death in the thalamus area and improves motor function in stroke.

The histologic appearance of brain tissue shows decreasing damaged body cells of the neurons in the thalamus area in the group with rHuEPO therapy. The group with rHuEPO 10000 IU experienced the least amount of damage. Previous study has been shown that erythropoietin treatment protects brain from neuronal demage when initiated soon after stroke induction, mostly through the decrease in neuronal apoptosis (Siren et al 2001).
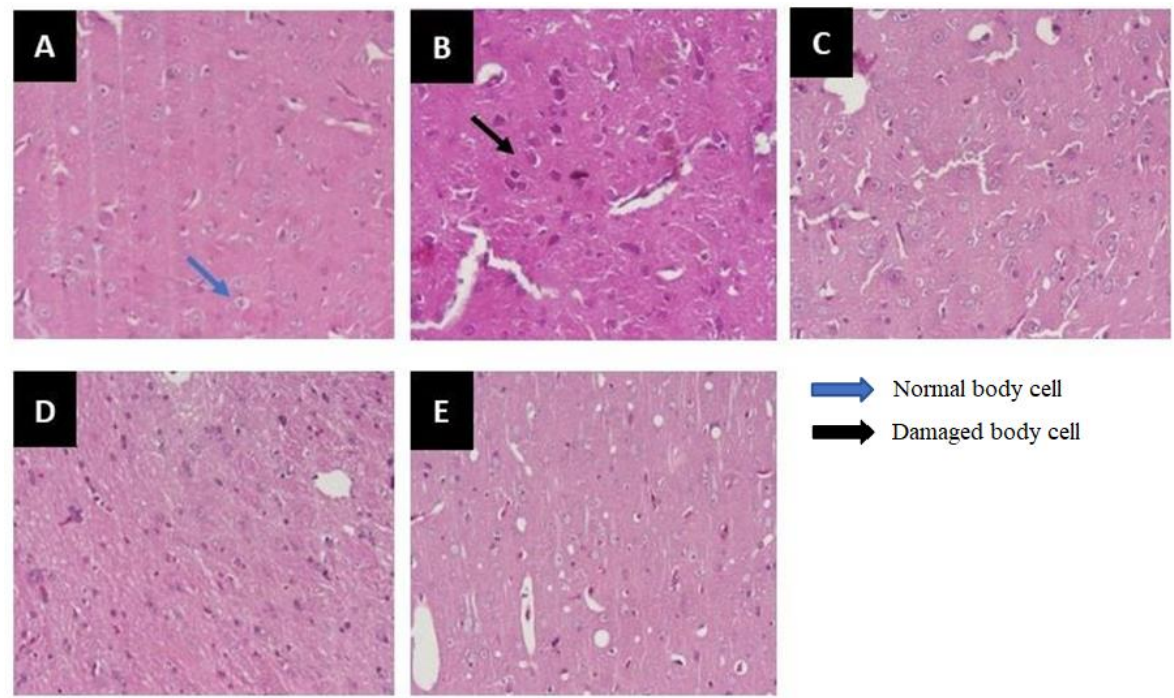

Fig. 2. Hematoxyllin eosin staining of brain samples 14 days after transient rUCCAO 90 min. A) Brain sections from sham (B) Stroke Model (C) Stroke Model + rHuEPO 1,000 IU (D Stroke Model + rHuEPO 5,000 IU and (E) Stroke Model + rHuEPO 10,000 IU. Infarct lesions were showed in thalamus area. Sections were examined at bregma $-2.00 \mathrm{~mm}$. 

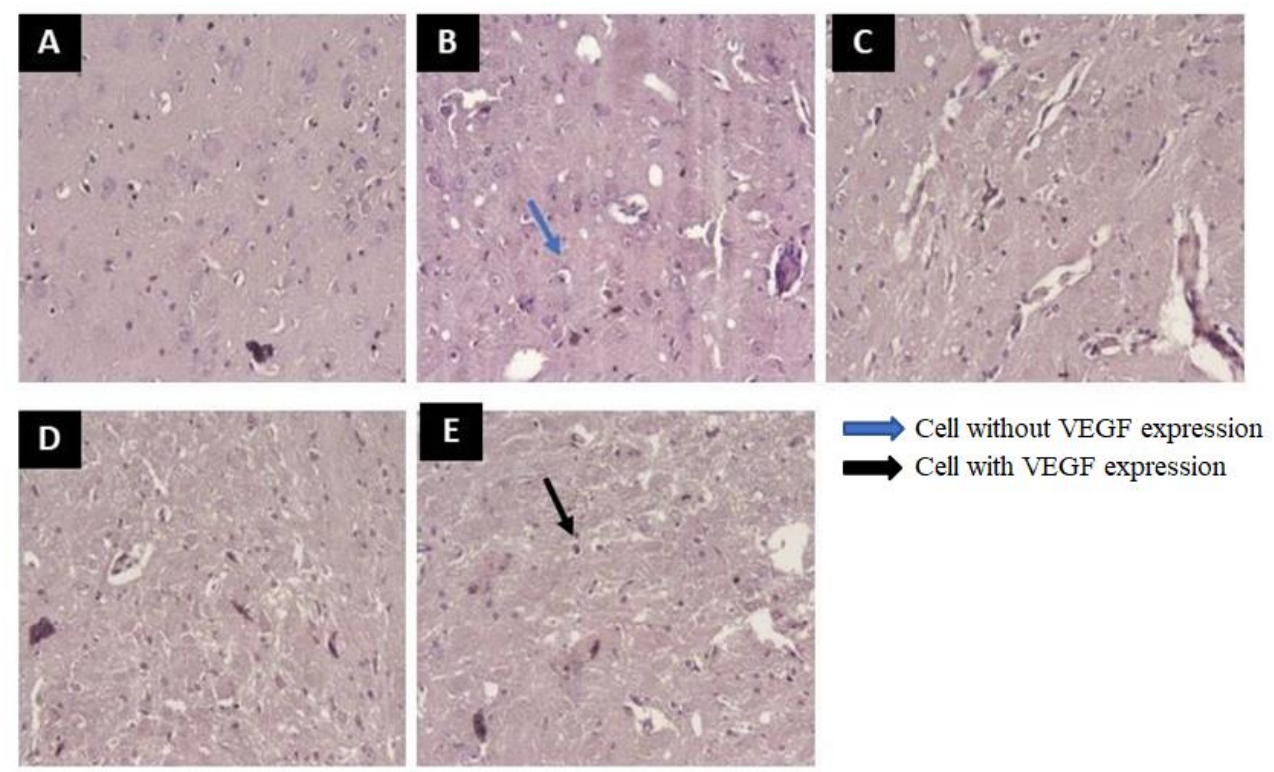

Fig. 3. Immunohistochemistry with VEGF antibody. A) Brain sections from sham (B) Stroke Model (C) Stroke Model + rHuEPO 1,000 IU (D Stroke Model + rHuEPO 5,000 IU and (E) Stroke Model + rHuEPO 10,000 IU. VEGF expression was showed in thalamus area. Sections were examined at bregma $-2.00 \mathrm{~mm}$. 400x magnification was used.

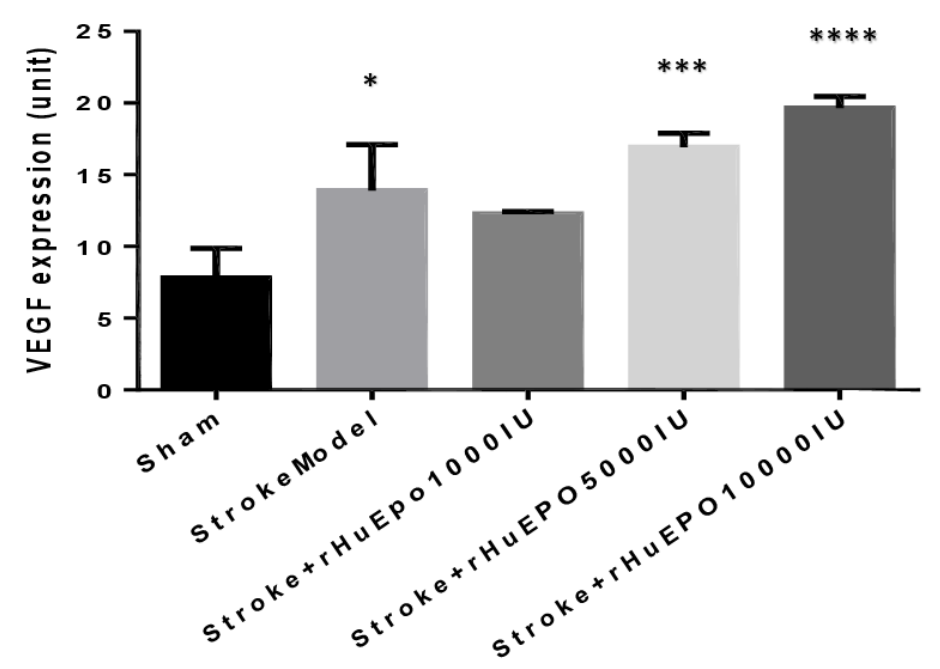

Fig. 4. VEGF expressions were examined in the sham group, stroke model, and stroke model group with rHuEPO of $1.000 \mathrm{IU} ; 5.000 \mathrm{IU}$ and 10.000 IU. Tukey's post-hoc test showed significant differences in the sham vs stroke model $(\mathrm{p}=0.0135)$, sham vs rHuEPO 5000 IU $(\mathrm{p}=0.0007),(\mathrm{p}=0.0191)$. ${ }^{*} \mathrm{p}<0.05$ vs sham.

Immunohistochemistry results showed that $\mathrm{rHuEPO}$ with doses of 5.000 IU and 10.000 IU significantly increased VEGF expression. It is reported that EPO promotes angiogenesis by EPO binding to its receptor (EPOR), thus phosphorylates and activates Janus tyrosine kinase 2 (JAK2). This leads to engaging secondary signaling molecules, such as signal transducer and activator of transcription 5 (STAT5), followed by the activation of Ras mitogen activated protein kinase (MAPK), ERK-1/-2, and PI3K/Akt. Moreover, EPO induced the upregulation of the anti-apoptotic protein BCL-XL (Rabie \& Marti 2008). The PI3K/Akt and ERK1/2 signaling pathways mediates VEGF secretion after the binding of exogenous EPO with EPOR. VEGF secreted by neural progenitor cells along with VEGFR2 in cerebral endothelial cells promotes angiogenesis 
(Wang et al 2008). EPO induces angiogenesis through increasing VEGF expression (Wang et al 2004).

\section{CONCLUSION}

rHuEPO may restore motoric function and prevent brain neuronal death by inducing angiogenesis through the increase in the expression of VEGF.

\section{ACKNOWLEDGMENT}

This work was supported by research grants "Hibah Riset Tahun 2017" from the Faculty of Pharmacy, Universitas Airlangga, Surabaya, Indonesia.

\section{REFERENCES}

Bruno A, Kaelin DL, Yilmaz EY (2000). The Subacute Stroke Patient: hours 6 to 72 after stroke onset. In Cohen SN. Management of Ischemic Stroke. New York, McGraw-Hill, p 53-87

Deb P, Sharma S, Hassan KM (2009). Pathophysiologic mechanisms of acute ischemic stroke: An overview with emphasis on therapeutic significance beyond thrombolysis. Pathophysiology 17, 197-218

Gandin C, Widman C, Lazdunski M, et al (2016). MLC901 favors angiogenesis and associated reco-very after ischemic stroke in mice. Cerebrovascular Disease 42,139-154

Gonzalez RG, Hirsch JA, Lev MH et al (2011). Acute ischemic stroke. London New York, Springer Heidelberg Dordrecht

Hacke W, Kaste M, Bogousslavsky J, et al (2003). Ischemic stroke prophylaxis and treatment. European Stroke Initiative Recommendations

Hellewell SC, Yan EB, Alwis DS, et al (2013). Erythropoietin improves motor and cognitive deficit, axonal pathology, and neuroinflammation in a combined model of diffuse traumatic brain injury and hypoxia, in association with upregulation of the erythropoietin receptor. Journal of Neuroinflammation 10, 156

Hoke, A. 2006. Erythropoietin and The Nervous System. John Hopkins University, Springer, p 25-101

Hua Y, Schallert T, Keep RF, et al (2002). Behavioral Tests After Intracerebral Hemorrhage in the Rat. Stroke 33, 2478-2484

Jin R, Yang G, Li G (2010). Inflammatory Mechanisms in Ischemic Stroke: Role of Inflammatory Cells. Journal of Leucocyte Biology 87

Ovbiagele B, Huynh MN (2011). Stroke Epidemiology: Advancing Our Understanding of Disease Mechanism and Therapy. The American Society for Experimental NeuroTherapeutics 8, 319-329

Park SY, Marasini S, Kim GH, et al (2014). A Method for Generate a Mouse Model of Stroke. Experimental Neurobiology 23 (1), 104-114

Pun PB, Lu J, Moochhala S (2009). Involvement of ROS in BBB dysfunction. Free Radical Research 43, 348-364

Rabie T, Marti HH (2008). Brain Protection by Erythropoietin: A Manifold Task. Physiology 23, 263-274

Ribatti D, Vacca A, Roccaro AM, et al (2003). Erythropoietin as an angiogenic factor. European Journal of Clinical Investigation, 891-896

Siren AL, Fratelli M, Brines M, et al (2001). Erythropoietin prevents neuronal apoptosis after cerebral ischemia and metabolic stress. Proceedings of the National Academy of Sciences USA 98, 4044-4049

Vikman, P, Ansar S, Henriksson M, et al (2007). Cerebral ischemia induces transcription of inflammatory and extracellular-matrix-related genes in rat cerebral arteries. Experimental Brain Research 183, 499- 510

Wang L, Chopp M, Gregg SR, et al (2008). Neural progenitor cells treated with EPO induce angiogenesis through the production of VEGF. Journal of Cerebral Blood Flow and Metabolism 28, 1361-1368

Wang L, Zhang Z, Wang Y, et al (2004). Treatment of stroke with erythropoietin enhances neurogenesis and angiogenesis and improves neurological function in rats. Stroke 35, 1732-1737 